\title{
Post-COVID-19 Syndrome in Egyptian Healthcare Staff: Highlighting the Carers Sufferings
}

\author{
Heba Mohamed Tawfik ${ }^{1,2 \star}$, Hassan Mohamed Shaaban ${ }^{3}$, Ahmed Mohamed Tawfik ${ }^{4}$
}

\author{
${ }^{1}$ Senior Lecturer and Consultant of Geriatrics and Gerontology at Faculty of Medicine, Ain-Shams University, Cairo, EGYPT \\ ${ }^{2}$ Member of Ain-Shams Ageing Research Center, Ain-Shams Cognitive Training Lab, Cairo, EGYPT \\ ${ }^{3}$ Pediatric and Neonatology Resident at the Ministry of Health and Population, Emergency Room and Sports Medicine Physician at the American University in Cairo, \\ Cairo, EGYPT \\ ${ }^{4}$ Lecturer and Consultant of Internal Medicine and Nephrology at Faculty of Medicine, Ain-Shams University, Cairo, EGYPT \\ *Corresponding Author: hmt_82@yahoo.com
}

Citation: Tawfik HM, Shaaban HM, Tawfik AM. Post-COVID-19 Syndrome in Egyptian Healthcare Staff: Highlighting the Carers Sufferings. Electron J Gen Med. 2021;18(3):em291. https://doi.org/10.29333/ejgm/10838

\section{ARTICLE INFO}

Received: 2 Feb. 2021

Accepted: 13 Mar. 2021

\begin{abstract}
Background: Coronavirus disease (COVID-19) represents a devastating crisis continuing for more than a year up till now with new emerging presentations and complications every now and then.

Aim: to spot the light on long-term symptoms in healthcare staff who are the first defence line in this pandemic and whose medical and psychological sufferings are underrepresented in studies.

Methods: 120 male and female participants working in Ain-Shams University and Ministry of health and population hospitals who had been infected with COVID-19 virus at least 3 months ago were recruited. Presenting symptoms, staging, medications, symptoms 1 month and more than 3 months after infection were recorded.

Results: The study participants aged between 23 and 62 years. fever was the most common presentation $57.5 \%$ followed by body aches in $44.2 \%$ and then anosmia in $41.7 \%$ of participants. Cough, dyspnea, fatigue and diarrhea were present in $37.5 \%, 33.3 \%, 35 \%$ and $19.2 \%$ respectively. Facial palsy and transient ischemic attack were presented each in one participant. Five participants experienced myocardial and pulmonary infarctions. Still $26.7 \%$ and $33.3 \%$ had dyspnea and fatigue after 3 months, 3 participants received antidepressants, 4 had memory problems. Parosmia, hair loss, oral ulcers and syncopal attacks emerged months after recovery. Odds ratio for symptoms after 3 months was 2.4 higher in participants aged $\geq 35$ years.

Conclusion: COVID-19 infection is unique in presentation and long-term symptoms which needs further large
\end{abstract} number of studies. Even young people and those with mild disease experience long term problems.

Keywords: COVID-19, healthcare workers, long term symptoms

\section{INTRODUCTION}

Over 100 million people were infected with the novel coronavirus disease (COVID-19) and more than 2.5 million people died since December 2019, when it was first detected in China. In Egypt, the reported cases exceeded 180,000 with more than 11000 deaths [1]. According to the Egyptian Medical Syndicate, more than 390 deaths were recorded in physicians up till now [2], apart from deaths of nurses, dentists, pharmacists, and other healthcare workers which were not recorded.

In September 2020, the Pan American Health Organization (PAHO) reported that nearly 570,000 healthcare workers were infected with COVID-19 in the United States only, of whom more than 2500 personnel died [3]. At the end of October, the International Council of Nurses (ICN) declared death of about 1500 nurses from the start of pandemic, though analysis was done in 44 countries only. ICN also suggested that $10 \%$ of cases worldwide were among healthcare workers [4].
Healthcare workers who are the frontlines of defence against COVID-19 pandemic have a greater risk of infection, because of frequent and prolonged contact with large numbers of infected patients, lack of availability of personal protective equipment (PPE), inadequate training in infection control on some occasions, and due exposure to unrecognized COVID-19 patients $[5,6]$.

On the $6^{\text {th }}$ of November 2020, the Centers for Disease Control and prevention (CDC) updated the definition of 'prolonged' contact to the cumulative period of exposure of 15 minutes or more to an infected person(s) during 24-hour period (which is the case in almost all physicians and nurses dealing with COVID-19 patients), though precise data is insufficient. In addition, any exposure is considered prolonged if it occurs during performance of an aerosol generating procedure [7].

Persistent symptoms were reported among patients recovered from COVID-19 infection, even those who initially had a mild acute illness, which represents a challenge. Another peculiar finding was that the young survivors, including those who were physically fit prior to infection, had also reported symptoms months after acute illness [8,9]. 
The most common symptoms recorded include fatigue, dyspnea, chest pain, etc. Other reported symptoms include myalgia, headache, fever, and palpitations. Serious complications appeared also but were less common, like ventricular dysfunction, pulmonary function abnormalities, acute kidney injury, cognitive impairment, depression, and anxiety [10-13].

Unfortunately, scarce studies were done reporting persistent COVID-19 symptoms and complications in healthcare workers, which should be revealed.

\section{SUBJECTS AND METHODS}

A retrospective cohort study recruiting 120 healthcare workers (physicians, nurses, dentists, and pharmacists) working in Ain-Shams University and Ministry of health and population hospitals who had been infected with COVID-19 virus at least 3 months ago. Participants were diagnosed by both polymerase chain reaction (PCR) for COVID-19 infection and $C T$ chest for categorizing severity and determining the appropriate treatment.

The study aimed to detect post-COVID-19 syndrome in healthcare staff, the carers in this pandemic. Data were collected regarding age, medical diseases, presenting symptoms of COVID-19, stage of disease, medications received and occurrence of serious thrombotic complications including myocardial infarction, pulmonary infarctions, and cerebrovascular strokes. As there is no consensus definition about timing of post-covid symptoms, we followed Greenhalgh and colleagues [14] who defined post-acute COVID-19 as those symptoms extending beyond three weeks from their onset and chronic COVID-19 refers to those extending beyond 12 weeks. Therefore symptoms 1 month and more than 3 months after infection were recorded and whether these symptoms needed medical treatment or interventions was also recorded.

Severity of COVID-19 infection was classified according to the National Institutes of Health (NIH) [15] into: asymptomatic infection: patients who test positive for COVID-19 but have no symptoms, mild disease: patients with any of these signs and symptoms (eg, fever, cough, sore throat, headache, malaise, muscle pain) without dyspnea, or abnormal imaging, moderate: patients with clinical evidence of lower respiratory disease or by imaging and an oxygen saturation ( $\mathrm{SaO} 2) \geq 94 \%$ on room air , severe disease: patients with a respiratory rate of over 30 breaths per minute, $\mathrm{SaO} 2$ up to $93 \%$ on room air, or more than $50 \%$ lung infiltrates on imaging and critical illness: those with respiratory failure, septic shock, and/or multiple organ dysfunction.

After recording symptoms, we divided the participants into 2 groups, those below 35 years of age and those 35 years and above to calculate odds ratio for occurrence of symptoms at 1 month and after 3 months. We considered that participants aged 35 years, and more were at higher risk as all thromboembolic complications in the study occurred in staff aged between 35 and 48 years. Each group was further subdivided according to absence of symptoms or the presence of one or more symptoms.

\section{Consent and Ethics}

Informed consents were taken from all participants at the start of the study. The study was approved by the Research Ethics Committee, Faculty of Medicine, Ain-Shams University
Table 1. Demography and characteristics of the study population

\begin{tabular}{|c|c|c|}
\hline & $\begin{array}{c}\text { Number of } \\
\text { participants } \\
\text { (total 120) or } \\
\text { mean }\end{array}$ & $\begin{array}{l}\text { Percent } \% \\
\quad \text { or } \\
+/- \text { SD }\end{array}$ \\
\hline Age & 33.7 & 7.29 \\
\hline \multicolumn{3}{|l|}{ Gender } \\
\hline Females & 70 & $58 \%$ \\
\hline Males & 50 & $42 \%$ \\
\hline \multicolumn{3}{|l|}{ Smoking } \\
\hline Non-smokers & 115 & $96 \%$ \\
\hline Smokers & 5 & $4 \%$ \\
\hline \multicolumn{3}{|l|}{ Comorbidities } \\
\hline HTN & 8 & $6.7 \%$ \\
\hline DM & 5 & $4 \%$ \\
\hline Cardiac disease & 3 & $2.5 \%$ \\
\hline Hypothyroidism & 4 & $3.3 \%$ \\
\hline Bronchial asthma & 9 & $7.5 \%$ \\
\hline Neurologic disease & 2 & $1.7 \%$ \\
\hline $\begin{array}{l}\text { Anemia } \\
\end{array}$ & 1 & $0.8 \%$ \\
\hline Number of hospitalized participants & 18 & $15 \%$ \\
\hline \multicolumn{3}{|l|}{ Severity of COVID-19 infection } \\
\hline $\begin{array}{c}\text { Mild } \\
\end{array}$ & 74 & $61.7 \%$ \\
\hline Moderate & 34 & $28.3 \%$ \\
\hline $\begin{array}{c}\text { Severe } \\
\end{array}$ & 12 & $10 \%$ \\
\hline \multicolumn{3}{|c|}{ Therapy received for COVID-19 infection } \\
\hline Oxygen therapy & 12 & $10 \%$ \\
\hline Steroid therapy & 45 & $37.5 \%$ \\
\hline Anticoagulation & 44 & $36.7 \%$ \\
\hline $\begin{array}{c}\text { Antiviral treatment } \\
\end{array}$ & 19 & $15.8 \%$ \\
\hline Occurrence of serious complications & At 1 month & After 3 months \\
\hline $\begin{array}{c}\text { Myocardial infarction } \\
\end{array}$ & $2(1.7)$ & \\
\hline Pulmonary infarctions & $3(2.5)$ & \\
\hline Pericardial effusion & $1(0.8)$ & \\
\hline
\end{tabular}

$\mathrm{SD}=$ standard deviation

$\mathrm{HTN}=$ hypertension

$\mathrm{DM}=$ diabetes mellitus

which operated according to guidelines of the International Council on Harmonization and the Islamic Organization for Medical Sciences, the United States Office for Human Research Protections, and the United States Code of Federal Regulations.

\section{Statistical Analysis}

The collected data was cross-checked, coded, tabulated using statistical package for social science (SPSS 20). The mean and standard deviation ( \pm SD) were used for parametric numerical data. Frequencies and percentages were used of non-numerical data. Odds ratio was calculated using Chi square test. Values $P$ - values indicated the level of significance with $p>0.05$ was considered being non-significant (NS), $p<0.05$ being significant $(S), p<0.01$ being highly significant $(H S)$.

\section{RESULTS}

The study participants aged between 23 and 62 years with the mean age 33.7 as shown in Table 1 . Indeed 21 participants were 40 years of age and above and the rest were twenties and thirties as they were more cooperative and willing to participate. The number of females (70) exceeded the males (50) as most of nurses were females. The study included 25 nurses, 10 pharmacists and the rest were physicians from different specialities (i.e., chest, geriatrics, anaesthesia, 


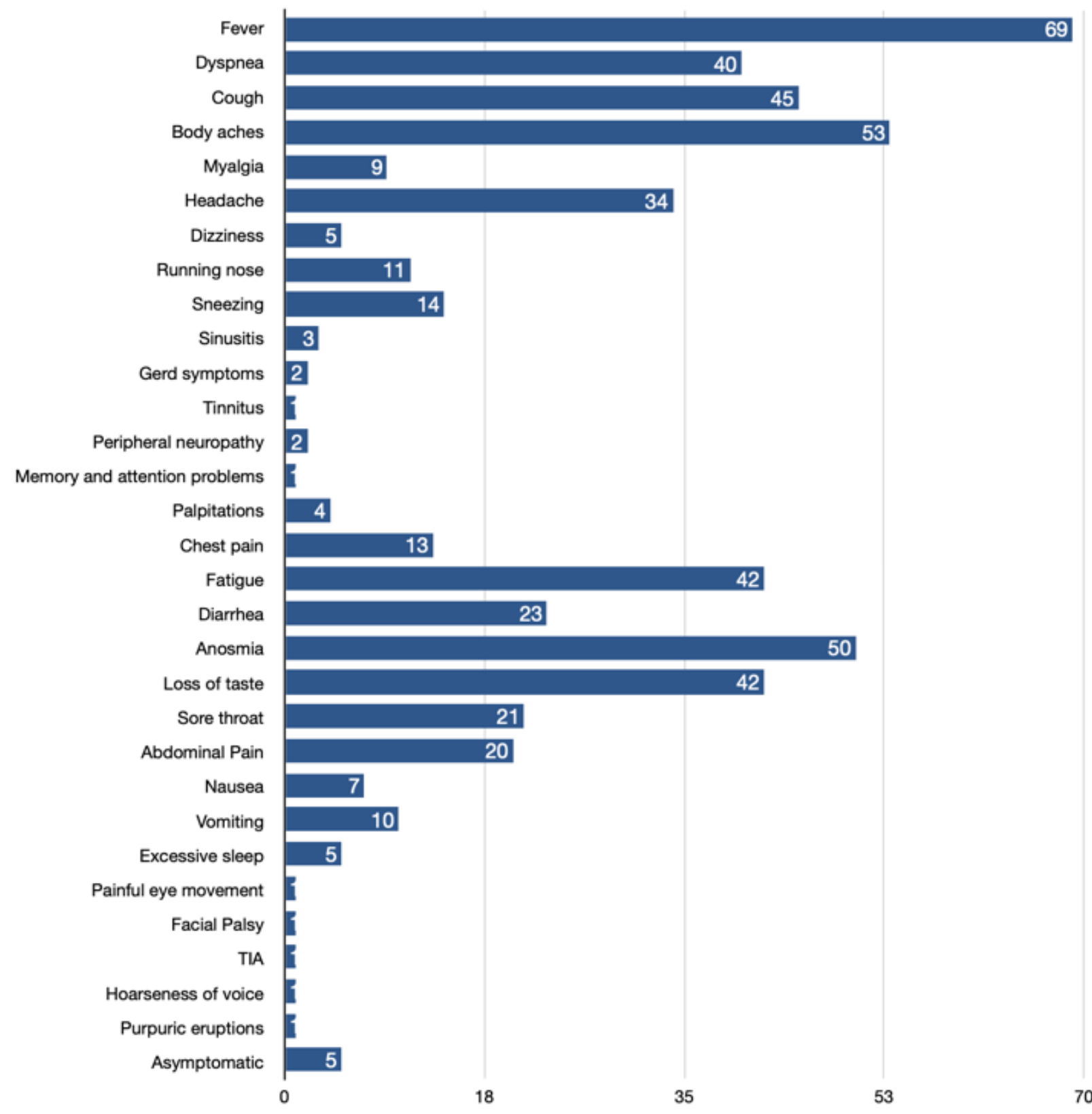

Figure 1. Manifestations of COVID-19 infection in participants $(\mathrm{N}=120)$. Numbers written are number of participants

cardiology, pediatrics, radiology, internal medicine, surgery, gynaecology, etc.) and dentists. Only 4 were obese and 5 of participants were smokers. Bronchial asthma was found in 9 and hypertension in 8 of participants, exceeding diabetes mellitus, cardiac diseases (ischemic, rheumatic heart disease and atrial fibrillation), and hypothyroidism. Only 2 had neurological diseases (one had multiple sclerosis and the other had sciatica), so most the study participants were medically free. Although 46 participants had moderate and severe infection, only 18 were hospitalized, as most of participants with moderate infection preferred to be treated at home with home isolation. Isolation in quarantine hospital was obligatory for all positive cases only at the start of pandemic in Egypt.

Figure 1 showed that the most common presenting symptom was fever in 69 participants $(57.5 \%)$ followed by body aches in $53(44.2 \%)$ and then anosmia in 50 (41.7\%). Cough, dyspnea and fatigue were present in $45(37.5 \%), 40$ (33.3\%) and $42(35 \%)$ participants, respectively. Headache was not uncommon, in $34(28.3 \%)$ and diarrhea was present in 23
(19.2\%) participants. Although uncommon (in 1 participant each), serious manifestations were reported like transient ischemic attack (TIA) which was one of the presenting symptoms in a female physician in $4^{\text {th }}$ decade who was medically free, she had dysphagia, slurred speech, and loss of face sensation in one side lasting about a day. The other reported serious problems were painful eye movements, facial palsy, memory problems and purpuric eruptions.

At 1 month about $75 \%$ of participants complained of fatigue and more than 50\% had dyspnea as shown in Figure 2, and these symptoms disappeared in about half of them only after 3 months. Body aches and myalgia persisted in about $18 \%$ of participants after 3 months. Although chest pain and palpitations were not amongst the most common presenting symptoms in our participants, these symptoms increased much at 1 month and 3 of our participants received rate control drugs for persistent tachycardia (after performing investigations) about 4 or 5 months after illness. Anosmia and loss of taste persisted in a considerable number and parosmia 


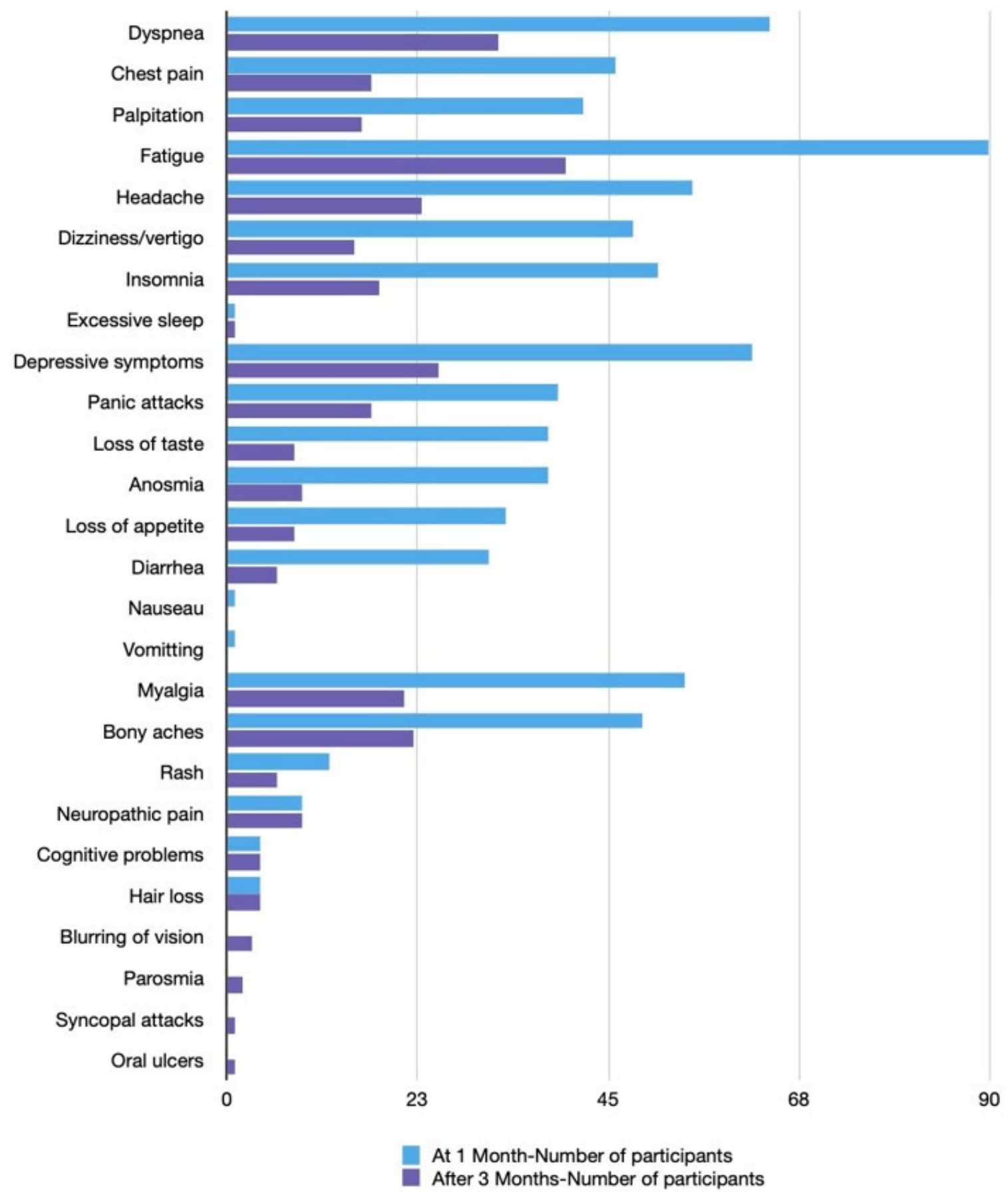

Figure 2. Post-COVID-19 acute and chronic symptoms at 1 month and after 3 months and complications in participants

with experiencing awfully bad smell in fish, chicken and meat appeared in 2 participants after 4 months of acquiring infection and they became vegetarian. Diarrhea, dizziness (and sometimes vertigo) and rash increased also at 1 month and one of participants continued anti-diarrheal drugs for 4 months after recovery. Regarding neuropsychiatric manifestations, depressive symptoms were present in about half and panic attacks occurred in about third of them at 1 month, decreased after 3 months but 3 were diagnosed as having major depression and started antidepressants. Neuropathic pain not explained by other illness became apparent in $7.5 \%$ requiring treatment in some of them. Insomnia also became more prominent, and 4 participants had memory and attention problems persisting months after recovery.
Painful eye movements which occurred in a female dentist, persisted for 4 months till now and were associated with decreased visual acuity but we have no more details. Whether this is due to optic neuritis or not is not clear. She received dexamethasone once at the start of illness. Another male physician is still receiving treatment for facial palsy 6 months following infection. Both were 29 years old and were medically free before illness.

The 6 male and female participants who developed myocardial, pulmonary infarctions and pericardial effusion aged between 35-41 years, were medically free (but 2 were obese), non-smokers, apart from one female who aged 48 years and was hypertensive.

Table 2 revealed that participants aged $\geq 35$ years are 2.4 times liable to develop symptoms after 3 months with relative 
Table 2. Odds ratio and relative risk for the presence of 1 or more symptoms after 3 months

\begin{tabular}{lccc}
\hline $\begin{array}{c}\text { Age } \\
\geq 35 \text { years } \\
<35 \text { years }\end{array}$ & P value & $95 \% \mathrm{Cl}$ \\
\hline OR for symptoms after 3 months & 2.408 & 0.0316 & 1.0807 to 5.3670 \\
\hline RR for symptoms after 3 months & 1.3674 & 0.0238 & 1.0425 to 1.7936 \\
\hline
\end{tabular}

OR= odds ratio

$\mathrm{RR}=$ relative risk

$\mathrm{Cl}=$ confidence interval

risk 1.37. We failed to calculate odds ratio for symptoms at 1 month as none of participants aged $\geq 35$ years were asymptomatic at that time.

\section{DISCUSSION}

To the best of our knowledge this is one of few studies in Egypt reporting post-COVID-19 Syndrome. The aim was to spot the light on such problems (which may affect function, social life or become disabling) in healthcare staff who work in incredibly stressful situations from the start of pandemic with lack of protective equipment in many instances, face the highest viral load and return to work without full recovery because of staff deficiency in some cases.

Symptoms like fatigue, dyspnea, dizziness, chest pain, headache, insomnia were reported by many participants months after recovery. Although they are subjective but to be taken into consideration, as we deal with healthcare staff who will report complaint in an accurate way in most cases and whose complaints are not the focus of attention. Similar symptoms were reported in other studies [8,16-18].

Even participants who presented with mild symptoms had persistent symptoms months later and many developed more or new symptoms after 3 months like hair loss and oral ulcers. This may be due to heightened inflammatory response in symptomatic COVID-19 promoting persisting symptoms. Some authors also suggest that posttraumatic stress disorder after COVID-19 could be accused in prolonged experience of some symptoms such as fatigue, generalized aches or poor wellbeing $[19,20]$. This could be true as many participants had depressive symptoms at 1 month and about third of them experienced at least one panic attack.

More than $30 \%$ had anosmia at 1 month, which was not a well-known symptom at the start of pandemic and was revealed thereafter. It was also reported by many researchers like Lechien and colleagues [21] who found persistent olfactory dysfunction in $37.5 \%$ of their patients at least 7 days after recovery of mild to moderate illness. In the wall Street Journal [22], Dr Jane Parker reported while studying 45 participants infected with COVID-19, 15 developed parosmia.

Searching for painful eye movements in COVID-19, we found a case report about bilateral optic neuritis in a 44-yearold medically free male who complained of painful eye movements and severe deterioration of visual acuity after acquiring infection [23]. Unfortunately, we do not have available fundus examination for our lady, but it was worthy declaration.

Recurrent syncopal attacks were reported in one participant after 3 months. Singhania and colleagues (24) reported syncope as the presenting symptom in an elderly female. These atypical symptoms if appeared early may cause more spread of infection in healthcare workers.
Myocardial infarction was reported in 2 male participants in late thirties and early forties. Whether COVID-19 patients in this age group are more liable is not known. Generally, studies found that not only does the virus cause hypercoagulable state, vascular inflammation, and plaque disruption, but also direct myocardial infection and inflammation [25,26]. COVID19 was also associated with higher risk of developing venous thromboembolism, though not reported in our research. Doses and duration of anticoagulation should be strictly determined according to clinical guidelines and regarding risk versus benefits in individual basis to avoid bleeding from long-term anticoagulation or antiplatelet therapy [27].

Regarding the male presented with pericardial effusion, Suaer et al. [28] reported 3 cases of pericardial effusion in the same cardiac centre after COVID-19 infection with 2 of them developing tamponades.

Being more at risk for long term symptoms and complications in late thirties and forties than twenties needs further studies and research. Finally, we would like to declare that the study is more descriptive focusing on symptoms, clinical and psychological sufferings of healthcare staff and was not studying predictors or risk factors for severe COVID-19 infection.

\section{CONCLUSION}

COVID-19 infection is unique in presentation and long-term symptoms which need further large number of studies to reveal the hidden pathology of many symptoms and complications appeared and the new ones which appear every now and then. Even young people and those with mild disease experience long term problems.

Author contributions: All authors have sufficiently contributed to the study, and agreed with the results and conclusions.

Funding: Authors declare that there is no financial support for this paper.

Declaration of interest: The authors declare that they have no competing interest.

\section{REFERENCES}

1. Johns Hopkins University of Medicine Coronavirus Resource Center. COVID-19 dashboard by the Center for Systems Science and Engineering (CSSE) at Johns Hopkins University (JHU). https://coronavirus.jhu.edu/map.html/ (Accessed: 12 March 2021).

2. https://new-v.ems.org.eg/ar/ (Accessed: 12 March 2021).

3. https://www.paho.org/en/news/2-9-2020-covid-19-hasinfected-some-570000-health-workers-and-killed-2500americas-paho/ (Accessed: 14 December 2020). 
4. https://www.icn.ch/news/icn-confirms-1500-nurses-havedied-covid-19-44-countries-and-estimates-healthcareworker-covid/ (Accessed: 14 December 2020).

5. Wang J, Zhou M, Liu F. Reasons for healthcare workers becoming infected with novel coronavirus disease 2019 (COVID-19) in China. J Hosp Infect. 2020 May;105(1):100-1. https://doi.org/10.1016/j.jhin.2020.03.002 PMid:32147406 PMCid:PMC7134479

6. Heinzerling A, Stuckey MJ, Scheuer T, Xu K, Perkins KM, Resseger H, Magill S, Verani JR, Jain S, Acosta M, Erin Epson. Transmission of COVID-19 to Health Care Personnel During Exposures to a Hospitalized Patient - Solano County, California, February 2020. MMWR Morb Mortal Wkly Rep 2020;69:472-6. https://doi.org/10.15585/mmwr.mm6915e5 PMid:32298249 PMCid:PMC7755059

7. https://www.cdc.gov/coronavirus/2019ncov/hcp/guidance-risk-assesment-hcp.html/ (Accessed: 14 December 2020).

8. Assaf G, Davis H, McCorkell L, Wei H, Brooke O'N, Akrami A, Low R, Mercier J, et al. What does COVID-19 recovery actually look like? An analysis of the prolonged COVID-19 symptoms survey by Patient-Led Research Team. Patient Led Research, 2020. https://patientresearchcovid19.com/

9. Godlee F. Living with covid-19. BMJ 2020;370:m3392. https://doi.org/10.1136/bmj.m3392

10. Carfi A, Bernabei R, Landi F, Gemelli Against COVID-19 PostAcute Care Study Group. Persistent symptoms in patients after acute COVID-19. JAMA. 2020;324(6):603-5. https://doi.org/10.1001/jama.2020.12603 PMid:32644129 PMCid:PMC7349096

11. Halpin SJ, Mclvor C, Whyatt G, Adams A, Harvey O, McLean L, Walshaw C, Kemp S, Corrado J, Singh R, Collins T, J O'Connor R, Sivan M. Postdischarge symptoms and rehabilitation needs in survivors of COVID - 19 infection: A cross-sectional evaluation. J Med Virol. 2020;93(2):1013-22. https://doi.org/10.1002/jmv.26368 PMid:32729939

12. Puntmann VO, Carerj ML, Wieters I, Fahim M, Arendt C, et al. Outcomes of cardiovascular magnetic resonance imaging in patients recently recovered from coronavirus disease 2019 (covid-19). JAMA Cardiol. 2020;5(11):1265-73. https://doi.org/10.1001/jamacardio.2020.3557 PMid:32730619 PMCid: PMC7385689

13. Zhao YM, Shang YM, Song WB, Li Q, Xie H, Xu Q, Jia J, Li L, Mao H, Zhou X, Luo H, Gao Y, Xua A. Follow-up study of the pulmonary function and related physiological characteristics of COVID-19 survivors three months after recovery. E Clinical Medicine. 2020;25:100463. https://doi.org/10.1016/j.eclinm.2020.100463 PMid:32838236 PMCid:PMC7361108

14. Greenhalgh T, Knight M, A'Court C, Buxton M, Husain L. Management of post-acute covid-19 in primary care. BMJ 2020;370:m3026. https://doi.org/10.1136/bmj.m3026 PMid:32784198

15. https://www.covid19treatmentguidelines.nih.gov/overvie w/clinical-spectrum/ (Accessed: November 2020).

16. Carvalho-Schneider C, Laurent E, Lemaignen A, Beaufils E, Bourbao-Tournois C, Laribi S, Flament T, Ferreira-Maldent $N$, Bruyère $F$, Stefic $K$, Gaudy-Graffin $C$, Grammatico-Guillon L, Louis Bernard. Follow-up of adults with noncritical COVID-19 two months after symptom onset. Clin Microbiol Infect. 2020 Oct 5. https://doi.org/10.1016/ j.cmi.2020.09.052 PMid:33031948 PMCid:PMC7534895
17. Huang Y, Tan C, Wu J, Chen M, Wang Z, Luo L, Zhou X, Liu X, Huang X, Yuan S, Chen C, Gao F, Huang J, Shan H, Liu J. Impact of coronavirus disease 2019 on pulmonary function in early convalescence phase. Respir Res. 2020 Jun 29;21(1):163. https://doi.org/10.1186/s12931-020-01429-6 PMid:32600344 PMCid:PMC7323373

18. O'Keefe JB, Cellai M. Characterization of prolonged COVID19 symptoms and patient comorbidities in an outpatient telemedicine cohort. medRxiv. 2020 https://doi.org/10.1101/2020.07.05.20146886

19. Mahase E. Covid-19: what do we know about 'long Covid'? BMJ 2020;370:m2815. https://doi.org/10.1136/bmj.m2815 PMid:32665317

20. Xiao S, Luo D, Xiao Y. Survivors of COVID-19 are at high risk of posttraumatic stress disorder. Glob Health Res Policy 2020;5:29. https://doi.org/10.1186/s41256-020-00155-2 PMid:32514428 PMCid:PMC7273810

21. Lechien JR, Chiesa-Estomba CM, Place S, Van Laethem Y, Cabaraux P, Mat Q, Huet K, Plzak J, Horoi M, Hans S, Barillari MR, Cammaroto G, Fakhry N, Martiny D, Ayad T, Jouffe L, Hopkins C, Saussez S, COVID-19 Task Force of YO-IFOS. Clinical and epidemiological characteristics of 1,420 European patients with mild-to-moderate coronavirus disease 2019. J Intern Med 2020 Sep;288(3):335-44. https://doi.org/10.1111/joim.13089 PMid:32352202 PMCid: PMC7267446

22. https://www.wsj.com/articles/damaged-sense-of-smellin-covid-patients-holds-clues-to-how-recovery-mightwork-11606140319/ (Accessed: 30 December 2020).

23. Sawalha K, Adeodokun S, Kamoga GR. COVID-19-Induced Acute Bilateral Optic Neuritis. J Investig Med High Impact Case Rep. 2020 Jan-Dec;8:2324709620976018. https://doi.org/10.1177/2324709620976018 PMid:33238757 PMCid:PMC7705770

24. Singhania N, Bansal S, Singhania G. An Atypical Presentation of Novel Coronavirus Disease 2019 (COVID19). Am J Med. 2020 Jul;133(7):e365-e366. https://doi.org/ 10.1016/j.amjmed.2020.03.026 PMid:32320693 PMCid: PMC7167564

25. Shi S, Qin M, Shen B, Cai Y, Liu T, Yang F, Gong W, Liu X, Liang $J$, Zhao Q, Huang H, Yang B, Huang C. Association of Cardiac Injury with Mortality in Hospitalized Patients With COVID19 in Wuhan, China. JAMA Cardiol. 2020 Jul 1;5(7):802-10. https://doi.org/10.1001/jamacardio.2020.0950 PMid:32211816 PMCid:PMC7097841

26. Yang C, Jin Z. An Acute Respiratory Infection Runs Into the Most Common Noncommunicable Epidemic-COVID-19 and Cardiovascular Diseases. JAMA Cardiol. 2020 Jul 1;5(7):743744. https://doi.org/10.1001/jamacardio.2020.0934 PMid: 32211809

27. Singhania N, Bansal S, Nimmatoori DP, Ejaz AA, McCullough PA, Singhania G. Current Overview on Hypercoagulability in COVID-19. Am J Cardiovasc Drugs. 2020 Oct;20(5):393-403. https://doi.org/10.1007/s40256-020-00431-z PMid:32748336 PMCid:PMC7398761

28. Sauer F, Dagrenat C, Couppie P, Jochum G, Leddet P. Pericardial effusion in patients with COVID-19: case series. case series, European Heart Journal - Case Reports, October 2020;4(FI1):1-7. https://doi.org/10.1093/ehjcr/ ytaa287 PMid:33415315 PMCid:PMC749957 